\title{
PERBEDAAN NILAI KERJA GURU LAKI-LAKI DAN PEREMPUAN PADA MADRASAH BERBASIS PESANTREN DI PONOROGO
}

\section{THE DIFFERENCE OF MALE TEACHERS AND WOMEN TEACHERS WORK VALUES IN MADRASAH BASED ON PESANTREN IN PONOROGO}

\author{
Rahmawati Prihastuty \\ Jurusan Psikologi Fakultas Ilmu Pendidikan UNNES \\ email:rahmawati.prihastuty@mail.unnes.ac.id \\ Hanik Musyarofah \\ Jurusan Psikologi Fakultas Ilmu Pendidikan UNNES \\ email:hanikmusyarofah96@gmail.com \\ Aji Sofanudin \\ Balai Penelitian dan Pengembangan Agama Semarang \\ email:ajisofan@gmail.com
}

Naskah diterima tanggal 6 Maret 2020, Naskah direvisi tanggal 21 April 2020, Naskah disetujui tanggal 9 Juni 2020

\begin{abstract}
Abstrak
Nilai kerja merupakan suatu hal yang penting dalam bekerja, terlebih bagi guru madrasah. Penelitian ini bertujuan untuk mengetahui perbedaan nilai kerja guru laki-laki dan perempuan serta faktorfaktor pembentuk nilai kerja pada guru madrasah berbasis pesantren di Kabupaten Ponorogo Jawa Timur. Penelitian ini menggunakan mix methods dengan subjek penelitian sebanyak 111 guru madrasah berbasis pesantren, terdiri atas 54 laki-laki dan 57 perempuan. Temuan penelitian menunjukkan bahwa nilai kerja menurut guru laki-laki terdiri atas kualitas kepribadian, nilai religiusitas, kualitas akademik, nilai ukhuwah Islamiyah, nilai komitmen organisasi, kualitas profesional, status, dan nilai material. Sedangkan nilai kerja pada guru perempuan terdiri atas kualitas kepribadian, kualitas akademik, kualitas profesional, nilai religiusitas, nilai komitmen organisasi, nilai ukhuwah Islamiyah, achievement, status, dan nilai sosial. Faktor pembentuk nilai kerja guru laki-laki adalah kepribadian, lingkungan kerja, religiusitas, pemimpin, kebudayaan, stat us sosial ekonomi, dan kepuasan kerja. Faktor pembentuk nilai kerja pada guru perempuan terdiri atas faktor lingkungan kerja, kepribadian, status sosial ekonomi, kebudayaan, pemimpin, religiusitas, reward, dan kepuasan kerja.
\end{abstract}

Kata Kunci: nilai kerja, guru madrasah, ponorogo

\begin{abstract}
Work value is an important thing at work, especially for madrasa teachers. This study aims to determine differences in the work values of male and female teachers as well as the factors forming work values in pesantren-based madrasa teachers in Ponorogo Regency, East Java. This study uses mix methods with 111 subjects of pesantren-based madrasa teachers, consisting of 54 men and 57 women. The research findings show that work values according to male teachers consist of personality quality, religiosity value, academic quality, ukhuwah Islamiyah value, organizational commitment value, professional quality, status, and material value. While the work values of female teachers consist of personality quality, academic quality, professional quality, religious value, organizational commitment value, ukhuwah Islamiyah value, achievement, status, and social value. The factors forming the work values of male teachers are personality, work environment, religiosity, leaders, culture, socioeconomic status, and job satisfaction. The factors forming work values in female teachers consist of work environment, personality, socioeconomic status, culture, leaders, religiosity, reward, and job satisfaction.
\end{abstract}

Keywords: work value, madrasah teacher, ponorogo 


\section{PENDAHULUAN}

B anyak riset menunjukkan bahwa nilai kerja laki-laki dan perempuan berbeda. Hasil survei Hawthorne tahun 1927-1932 memperlihatkan bahwa lakilaki lebih memperdulikan mengenai upah dan kondisi kerja daripada perempuan. Sementara wanita lebih peduli tentang relasi sosial daripada laki-laki (Nie, Ye Luo, Wentworth, \& Sturkie, 2014:53-64). Penelitian serupa menujukkan bahwa wanita yang bekerja memiliki persentase tertinggi pada dimensi nilai otonomi, nilai prestasi dan asas mengutamakan orang lain yang memiliki nilai yang sama dengan nilai status (Putranto \& Ingarianti, 2014:128). Nilai kerja dipengaruhi oleh budaya (JM Ivancevich, R Konpaske, 2007: 42-43). Salah satu budaya Indonesia yang melekat erat di masyarakat yaitu budaya agama. Oleh karena itu, mengkaji nilai kerja di Indonesia belum tentu sama persis dengan negara lain.

Madrasah berbasis pesantren memiliki latar belakang pendidikan Agama Islam yang sangat kuat. Salah satu budaya dalam pendidikan Agama Islam seperti penekanan pada pencarian ilmu pengetahuan, penguasaan dan pengembangan atas dasar ibadah kepada Allah SWT (Nanat Fatah Natsir, 2007:26). Menurut Qardhawi ibadah yang dimaksud dalam Islam adalah semua yang dilakukan manusia di pekerjaannya untuk memenuhi kebutuhan dihidupnya baik kehidupan dunia atau akhirat (Abdullah, Omar, Nik Mutasim, \& Adham, 2013:123). Bekerja sebagai bentuk ibadah seharusnya menjadi salah satu bagian dari orientasi nilai kerja warga di lingkungan budaya Islam, seperti penelitian Suwardi menyatakan bahwa orientasi kerja warga STAIN Salatiga adalah kerja untuk imbalan, kerja untuk mencari bekal ibadah, dan kerja untuk ibadah (Suwardi, 2005:287).

Budaya pendidikan dalam madrasah yang menekankan pada penanaman nilai Agama Islam, terutama untuk membentuk akhlak yang baik dan mendasarkan pekerjaan sebagai bentuk ibadah kepada Allah SWT tentu berbeda dengan budaya kerja di sekolah umum. Sehingga penekanan nilai kerja pada guru madrasah tidak berorientasi pada kepuasan untuk memenuhi kebutuhan fisik, seperti upah dan kondisi kerja seperti pada hasil penelitian Hawthorne. Perbedaan corak budaya berpeluang memberi dampak yang berbeda pada nilai kerja guru madrasah di Kabupaten Ponorogo.

Kabupaten Ponorogo adalah salah satu Kabupaten di Jawa Timur yang memiliki lebih dari enam puluh pondok pesantren dengan berbagai tipe. Saat ini hampir semua pondok pesantren memiliki madrasah atau biasa disebut dengan madrasah berbasis pesantren. Madrasah pesantren merupakan madrasah yang bersistem pesantren, artinya siswa tinggal bersama kyai di pondok dan hidup dalam suasana belajar selama 24 jam (Setyaningsih, 2016:181). Sistem madrasah yang demikian diharapkan menjadi tempat belajar seni, ilmu, dan agama bagi siswa melalui peran guru madrasah sebagai tenaga pendidik.

Membahas guru madrasah pesantren sebagai bidang pekerjaan khusus yang bekerja berdasarkan prinsip-prinsip diatas, tidak terlepas dari pengertian bekerja. Menurut Gilmer bekerja itu merupakan proses fisik maupun mental manusia dalam mencapai tujuannya (As'ad, 2004: 47). Bekerja dalam Islam bukan hanya memuliakan diri sendiri, menampakkan kemanusiannya, tetapi sebagai wujud dari amal sholeh sehingga memiliki nilai ibadah yang luhur (Irham, 2012:16). Secara umum tujuan seseorang bekerja adalah mendapat kondisi yang lebih memuaskan daripada kondisi saat ini. Jadi, bekerja memiliki orientasi untuk mencapai kepuasan fisik dan mental (spiritual).

Aspek mental yang diduga kuat memberikan kontribusi bagi kinerja individu maupun perilaku kerja adalah nilai yang diyakini. Nilai yang ada dalam individu sejalan dengan pilihan pekerjaan (Judge \& Bretz, 1992:270). Pernyataan ini sesuai dengan hasil penelitian Meglino melaporkan meningkatnya kepuasan kerja dan komitmen kerja pekerja terjadi ketika nilai-nilai pekerja adalah kongkruen at au sama dengan nilai-nilai mereka terhadap pandangan ke depan (Meglino, Ravlin, \& Adkins, 1992:425). Dapat dikatakan bahwa, jika nilai kerja guru madrasah sesuai dengan nilai-nilai kehidupan 
guru madrasah secara otomatis akan meningkatkan kepuasan kerja dan komitmen kerja guru madrasah.

Penelitian terkait nilai kerja masih belum banyak dibahas di Indonesia. Terlebih pada madrasah berbasis pesantren yang sangat kental dengan nilai-nilai agama Islam, seperti membentuk siswa berakhlak karimah/akhlak baik dan mewajibkan siswa mengabdi selama lima tahun sebelum dinyatakan bebas dari madrasah pesantren, dimana hal ini sangat berbeda dengan budaya barat maupun budaya pada sekolah umum lainnya.

Berdasarkan latar penelitian dilakukan untuk mengetahui perbedaan nilai kerja guru laki-laki dan perempuan pada madrasah berbasis pesantren serta faktorfaktor pembentuk nilai kerja guru madrasah berbasis pesantren di Kabupaten Ponorogo Jawa Timur. Riset ini menggunakan pendekatan indigenous psikologi. Oleh karena itu hasil penelitian ini tidak dapat digeneralisasikan secara umum, tetapi hanya berlaku pada guru madrasah berbasis pesantren di Kabupaten Ponorogo terutama subjek yang terlibat dalam penelitian ini.

\section{TINJAUAN PUSTAKA}

\section{Nilai Kerja}

Menurut Van Pletsen nilai kerja merupakan variabel kepribadian dan bahwa itu terbentuk bersama-sama dengan kepribadian individu (Jayanti, Suharsono, \& Ingarianti, 2016: 80). Menurut Super (1969) konstruk nilai kerja didefinisikan sebagai bagian dari nilai total seperti kualitas, kepuasan, atau imbalan dari pekerjaan (Jayanti, Suharsono, \& Ingarianti, 2016: 80). Lebih jauh Wollack dkk (1971:331) menggambarkan nilai kerja lebih mengarah pada sikap seseorang terhadap pekerjaan secara umum, bukan perasaan mengenai pekerjaan tertentu . Perasaan bangga terhadap profesi hanya menjadi nilai inti yang bermakna kontemporer (Bisman, 2004: 109). Knoop (1994) menambahkan bahwa nilai kerja merujuk pada tingkatan nilai, kepentingan dan keinginan ditempat kerja (Knoop, 1994: 683).

Nilai kerja merupakan bentuk persepsi pekerja dari tempat kerja, secara langsung dapat mempengaruhi sikap dan perilaku, seperti nilai kerja keadilan (fairness) merupakan faktor penting pada pengambilan keputusan terkait kedisiplinan absen kerja (TA Judge, 1992: 22), pengambilan keput usan pekerjaan (Judge \& Bretz, 1992:270) dan persepsi serta penyelesaian masalah (Ravlin \& Meglino, 1987:425).

Li, Liu, dan Wan (2008) (Utama, 2013:217) menyatakan ada beberapa kualitas dalam nilai kerja, diantaranya : (a) keinginan seseorang terhadap pekerjaan yang dikerjakan; (b) memiliki sifat yang lebih mendasar daripada minat; (c) merefleksikan antara kebutuhan dengan kepuasan; (d) berisi preferensi-preferensi namun bukanlah imperatif moral; dan (e) kecenderungan umum untuk memilih suatu kondisi tertentu dibandingkan kondisi lainnya.

Berdasarkan pendapat tersebut dapat disimpulkan bahwa nilai kerja merupakan sikap dan perilaku seseorang terhadap pekerjaan secara umum mengenai kualitas, kepuasan dan imbalan yang diharapkan dari pekerjaan atau hasil akhir dari pekerjaan serta mengandung penilaian atas apa yang dianggap penting dari suatu pekerjaan.

Hofstade mengajukan empat dimensi nilai: jarak kekuasaan (power distance); penghindaran ketidakpastian (uncertainty avoidance); individualisme; maskulinitas (Ivencevich, J. M., Konopaske, R., \& Matteson, 2007: 42-43). Secara lebih jelas berikut merupakan tabel nilai dan dimensi kebutuhan:

Tabel 1 Deskripsi Nilai dan Kebutuhan

\begin{tabular}{ll}
\hline Nilai (value) & Kebutuhan (Need Scale) \\
\hline Prestasi (achievement) & Penggunaan kemampuan \\
& (ability utilization) \\
& Prestasi (achievement) \\
& Kegiatan (activity) \\
& Kebebasan (independence) \\
\hline Kenyamanan (comfort) & Variasi (variety) \\
& Kompensasi (compensation) \\
& Keamanan (security) \\
& Kondisi kerja (working \\
& condition) \\
& Kemajuan (advancement) \\
\hline Status (status) & Pengakuan (recognition) \\
& Wewenang (authority) \\
& Status sosial (social status) \\
\hline Azas mengutamakan & Rekan kerja (co-workers) \\
orang lain (altruism) & Nilai moral (moral values) \\
& Layanan sosial (social service) \\
\hline Keamanan (safety) & Praktek kebijakan perusahaan \\
& (company policies and \\
& practicies) \\
& Pengawasan \\
& (supervision human relations) \\
& Pengawas teknis (supervision \\
& technical) \\
\hline Otonomi (autonomy) & Kreativitas (creativity) \\
& Tanggungjawab (responsibilty) \\
\hline &
\end{tabular}


Tiga tokoh menyatakan dimensi nilai kerja yang berbeda, tetapi memiliki makna yang serupa. Dimensi nilai kerja menurut Minessota Importance Questionnaire dinilai paling operasional dan sesuai dengan penelitian yang hendak dilakukan, keenam dimensi nilai kerja yang dimaksud adalah prestasi, kenyamanan, status, asas mengutamakan orang lain, keamanan, dan otonomi.

\section{Faktor yang Mempengaruhi Nilai Kerja}

Menurut Chen (1995) pembentukan nilai kerja dapat dipengaruhi oleh beberapa faktor, diantaranya adalah faktor sejarah sosiologis, ekonomis, dan faktor historis. Pengaruh ini termasuk pengaruh etnis, subkult ur, peran seks, sejarah pengikut, stat us sosial ekonomi, dan kondisi ekonomi (Jayanti et al., 2016: 80).

Menurut Hofstade (1980:81-94) (Fikri, 2015: 44-45) faktor-faktor yang mempengaruhi nilai kerja adalah:

\section{a. Lingkungan}

Lingkungan mempengaruhi nilai kerja sesorang dalam bekerja, seperti lingkungan fisik dan orang dalam organisasi. Lingkungan ataupun situasi yang dialami oleh seseorang akan membuat munculnya dorongan untuk menilai pada suatu hal, demikian juga dengan nilai kerjanya. Hubungan interpersonal antara pegawai dengan teman sejawat maupun dengan atasan dan bahkan bawahan akan berdampak pada nilai kerja pegawai.

\section{b. Kepuasan}

Kepuasan karyawan dalam pekerjaannya menentukan nilai kerjanya. Kepuasan karyawan dipandang sebagai hal yang menyeluruh dari pekerjaannya, maka semakin puas karyawan terhadap pekerjaannya maka nilai mereka juga akan terpengaruh juga. Kepuasan kerja seseorang akan menentukan tinggi rendahnya nilai kerja seseorang, dan kepuasan ini juga menentukan lama tidaknya orang tersebut bekerja pada perusahaan.

\section{c. Tujuan Personal}

Tujuan personal merupakan target yang ingin dicapai oleh karyawan, yang menyebabkan karyawan akan mengerahkan seluruh kemampuan untuk mencapai tujuan. Tujuan personal dari karyawan dimana suatu hal yang ingin dicapai akan menjadi penentu bagaimana karyawan menggambarkan dan menentukan nilai kerjanya.

Berdasarkan pendapat tokoh diatas, dapat ditarik kesimpulan bahwa faktor yang membentuk nilai kerja adalah jenis kelamin, pendidikan, lingkungan, kepuasaan terhadap pekerjaan, dan tujuan personal.

\section{METODE PENELITIAN}

Penelitian ini menggunakan mix method. Pendekatan yang digunakan adalah indigenous psikologi. Menurut Kim dan Berry (1993) (Putri, A. K., Prawitasari, J. E., Hakim, M., Yuniarti, K. W., \& Kim, 2012: 29) indigenous psikologi diartikan sebagai studi ilmiah dari perilaku atau pikiran manusia yang asli, tidak berasal dari daerah lain, dan dirancang untuk masyarakatnya. Kim dan Park (2006) (Putri, A. K., Prawitasari, J. E., Hakim, M., Yuniarti, K. W., \& Kim, 2012: 29) menambahkan bahwa konsep itu menantang konsep teori psikologi pada umumnya. Tujuan utama penggunaan metode indigenous psikologi adalah menerapkan hasil penelitian secara kontekstual, jadi akan meminimalisir dalam penerapan bias budaya (Moordiningsih, 2010) (Primasari \& Yuniarti, 2012: 55). Pendekatan indigenous psikologi mencoba untuk memahami manusia (pikiran, perasaan, dan perilaku) dalam konteks lokal dari perspektif yang ada dalam diri responden (Primasari \& Yuniarti, 2012: 54-55).

Penggunaan studi indigenous dimaksudkan untuk menelaah budaya yang ada di pesantren Ponorogo, seperti mengabdi selama lima tahun tanpa mengharap imbalan apapun, kecuali mendapatkan keberkahan ilmu dari para kyai pondok dan ustadz ustadzah. Pemantapan panca jiwa pondok juga menjadi salah satu bagian penting dalam pesantren, seperti penguat an nilai keikhlasan, ukhuwah Islamiyah, bebas, berdikari dan jiwa kesederhanaan. 
Budaya-budaya yang demikian menjadi suatu keunikan tersendiri yang membedakan antara pesantren dengan sekolah pada umumnya. Sehingga studi indigenous dinilai sangat sesuai untuk membantu mengetahui konsep dan faktor nilai kerja menurut guru madrasah pesantren khusunya yang ada di Ponorogo.

Teknik pengumpulan data menggunakan wawancara, observasi, telaah dokumen, dan FGD (Focus Group Discussion). Partisipan dalam penelitian ini adalah seratus sebelas (111) guru madrasah pesantren di Kabupaten Ponorogo. Kriteria guru yang dijadikan partisipan adalah guru madrasah pesantren di Kabupaten Ponorogo, terdiri atas: Guru MI, Guru MTs, dan Guru MA.

Teknik sampling yang digunakan adalah snawball sampling, dimana peneliti menghubungi subjek penelitian yang memenuhi kriteria dan meminta subjek merekomendasikan teman, keluarga atau kenalan yang diketahui memenuhi kriteria, sehingga bersifat sambung-menyambung semakin lama jumlah sampel semakin banyak (Sugiyono, 2012: 85-86). Pengumpulan data dari subjek 1 sudah selesai, peneliti meminta rekomendasi untuk subjek ke-2, lalu subjek ke-2 juga diminta merekomendasikan seseorang, proses tersebut berlangsung demikian hingga peneliti mendapatkan data sesuai dengan kebutuhan peneliti.

Teknik analisis yang digunakan penjelasan ringkas dari seluruh unit dan menjelaskan perbedaan antar unit analisis sebagai berikut:

Tabel 2 Unit Analisis

\begin{tabular}{lll}
\hline $\begin{array}{l}\text { Unit } \\
\text { Analisis }\end{array}$ & Sub Unit Analisis & Pertanyaan \\
\hline \multirow{4}{*}{ Nilai Kerja } & $\begin{array}{l}\text { 1. Konsep nilai } \\
\text { kerja }\end{array}$ & $\begin{array}{l}\text { 1. Sebutkan nilai kerja } \\
\text { yang Anda miliki } \\
\text { sebagai guru madrasah } \\
\text { pesantren? }\end{array}$ \\
\cline { 2 - 3 } & $\begin{array}{l}\text { 2.Faktor-faktor } \\
\text { yang membentuk } \\
\text { nilai kerja }\end{array}$ & $\begin{array}{l}\text { saja yang membentuk } \\
\text { nilai kerja Anda? }\end{array}$ \\
\hline
\end{tabular}

(Morrisan, 2012: 48)

Selanjutnya subjek penelitian diminta menuliskan jawaban di tempat yang telah disediakan. Open-ended questionare dipilih sebagai alat pengumpul data karena mempunyai banyak kelebihan, seperti : (a) subjek bebas menjawab setiap aitem berdasarkan nilai dan pengalaman pribadinya, (b) respon atau jawaban dari aitem merepresentasikan ekspresi dan pendapat subjek, (c) peneliti dapat mengidentifikasi dan mengeksplor aspek yang ditemukan dalam topik penelitian secara lebih mendalam dan lebih luas (Hayes, 2000) (Rarasati, N., Hakim, M., \& Yuniarti, 2012: 1264).

\section{PEMBAHASAN}

\section{Nilai Kerja yang Dimiliki Guru Madrasah}

Temuan di lapangan mendapatkan tujuh puluh tujuh (77) kategori pada subjek laki-laki dan enam puluh empat (64) pada subjek perempuan. Koding pada pertanyaan dengan cara subjek diminta memberi jawaban minimal tiga jawaban. Selanjutnya dilakukan koding tahap kedua dengan teknik reduksi data diperoleh delapan (8) nilai kerja guru madrasah pesantren laki-laki terdiri atas: : (1) kualitas kepribadian; (2) kualitas akademik; (3) kualitas profesional; (4) nilai religiusitas (5) nilai material; (6) nilai status; (7) nilai ukhuwah Islamiyah; (8) nilai komitmen organisasi.

Enam puluh empat (64) kategori diperoleh dari proses koding pertama, selanjutnya melakukan koding tahap kedua dengan teknik reduksi data dan mendapatkan sepuluh (10) nilai yang dimiliki guru madrasah pesantren, yaitu: (1) kualitas kepribadian; (2) kualitas akademik; (3) kualitas profesional; (4) nilai religiusitas; (5) nilai status; (6) achievement; (7) ukhuwah Islamiyah; (8) komitmen organisasi; (9) nilai sosial; dan (10) lain-lain.

Berdasarkan temuan tersebut kemudian dibandingkan ant ara nilai kerja guru laki-laki dan nilai kerja guru perempuan.

Tabel 3 Perbedaan Nilai Kerja

\begin{tabular}{lll}
\hline No & Nilai Kerja Laki-Laki \\
\cline { 2 - 3 } & Laki-laki & Perempuan \\
\hline 1 & Kualitas Kepribadian & Kualitas Kepribadian \\
\hline 2 & Kualitas Akademik & Kualitas Akademik \\
\hline 3 & Kualitas Profesional & Kualitas Profesional \\
\hline 4 & Nilai Religiusitas & Nilai Religiusitas \\
\hline 5 & Nilai Material & - \\
\hline 6 & Nilai Status & Nilai Status \\
\hline 7 & Nilai Ukhuwah & Nilai Ukhuwan Islamiyah \\
& Islamiyah & Komitmen \\
\hline 8 & Nilai Nilai & Organisasi \\
\hline & Organisasi & Nilai Sosial \\
\hline 9 & - & Nilai Achievement \\
\hline 10 & - & \\
\hline
\end{tabular}


Berdasarkan tabel di atas diketahui bahwa nilai kerja perempuan lebih banyak daripada nilai kerja laki-laki. Pada nilai kerja guru perempuan tidak terdapat nilai material. Sementara pada nilai kerja guru laki-laki tidak terdapat nilai sosial dan achievement.

Temuan penelitian terkait skor persentase nilai kerja guru laki-laki dan nilai kerja guru perempuan adalah sebagai berikut:

Tabel 4 Persentase Nilai Kerja Guru

\begin{tabular}{llll}
\hline No & Nilai Kerja & $\begin{array}{l}\text { Laki-laki } \\
(\%)\end{array}$ & $\begin{array}{l}\text { Perempuan } \\
(\%)\end{array}$ \\
\hline 1 & $\begin{array}{l}\text { Kualitas } \\
\text { Kepribadian }\end{array}$ & 44,86 & 53,42 \\
\hline 2 & Kualitas Akademik & 9,70 & 12,50 \\
\hline 3 & Kualitas Profesional & 3,64 & 10,80 \\
\hline 4 & Nilai Religiusitas & 22,43 & 10,21 \\
\hline 5 & Nilai Material & 1,22 & - \\
\hline 6 & Nilai Status & 2,42 & 1,14 \\
\hline 7 & Nilai Ukhuwah & 8,48 & 3,41 \\
\hline & Islamiyah & & \\
\hline 8 & Nilai Komitmen & 7,27 & 4,35 \\
\hline 9 & Organisasi & Nilai Sosial & 1,14 \\
\hline 10 & Nilai achievement & - & 1,14 \\
\hline
\end{tabular}

Berikut ini penjelasan nilai kerja masing-masing unsur yaitu: (1) kualitas kepribadian, (2) kualitas akademik, (3) kualitas profesional, (4) nilai religiusitas, (5) nilai material, (6) nilai status, (7) nilai ukhuwah Islamiyah, (8) nilai komitmen organisasi, (9) nilai sosial, dan (10) nilai achievement.

\section{Kualitas Kepribadian}

Nilai kualitas kepribadian pada guru madrasah pesantren laki-laki sebesar 44,86\% sedangkan pada guru madrasah pesantren perempuan sebesar 53,42\%. Berdasarkan hasil ini maka nilai kualitas kepribadian pada guru madrasah perempuan lebih tinggi dibandingkan guru madrasah laki-laki. Kualitas kepribadian sendiri merupakan sifat, karakter maupun hal-hal positif yang menjadi ciri khas bagi individu. Beberapa sifat atau karakter yang menjadi bagian dari kualitas kepribadian adalah keteladanan atau dalam Islam dikenal dengan istilah uswatun khasanah, disiplin, berakhlak mulia, kejujuran, kreatif dan inovatif, bertanggungjawab, sopan, dan lain-lain.
Beberapa sifat dan karakter diatas menjadi salah satu bagian kompetensi guru yang profesional, yaitu kompetensi kepribadian. (Nanat Fatah Natsir, 2007: 22-23) mengartikan kompetensi kepribadian sebagai memiliki kepribadian yang mantap, berakhlak mulia, arif, bijaksana, menjadi teladan bagi siswa dan masyarakat, mampu menilai diri sendiri dan mengembangkan diri secara berkelanjutan.

Apabila ditinjau dari teori Rokeach sifat dan karakter seperti jujur, berakhlak mulia, menjadi teladan yang baik bertanggungjawab menjadi bagian dari nilai instrumental. Nilai instrumental merujuk pada perilaku yang lebih disukai atau cara-cara memperoleh nilai terminal. Aspek yang terkandung seperti kejujuran, kreatif dan inovatif, bertanggung jawab, disiplin (Rokeach) (Dayakisni, T., \& Yuniardi, 2012: 50).

\section{Kualitas Akademik}

Kualitas akademik berkaitan dengan bagaimana seorang guru mampu menunjukkan kualitas yang baik sebagai akademisi dalam proses pendidikan. Hasil lapangan menunjukkan kualitas akademik guru madrasah pesantren laki-laki sebesar 9,70\% dan $12,50 \%$ pada guru madrasah pesantren perempuan. Hasil ini membuktikan bahwa guru madrasah perempuan lebih mengutamakan kualitas pendidikan sebagai nilai kerja dibandingkan guru madrasah pesantren laki-laki. Kualitas akademik dalam penelitian ini terdiri dari kemampuan mengajar dan mendidik, menyampaikan materi dengan komunikatif, mempunyai nilai pendidikan, dan menguasai bahan ajar serta memberikan layanan BK dan instruksional kepada peserta didik.

Nilai kualitas akademik dalam penelitian ini hampir sama dengan kompetensi pedadogik. Menurut Natsir (2007) kompetensi pedagogik adalah kemampuan guru mengelola pembelajaran peserta didik minimal terkait pemahaman wawasan pendidikan, merancang dan melaksanakan pembelajaran, evaluasi belajar dan mengaktualisasikan potensi siswa (Nanat Fatah Natsir, 2007: 22-23). Nilai kualitas akademik juga mencerminkan 
karakter guru yang efektif (Al-Ghazali) (Dzulkifli, \& Sari, 2015: 90). Salah satu karakter guru yang efektif menurut AlGhazali adalah memberi bahan yang lebih mudah dipahami kepada peserta didik yang kurang pintar dan melayani (mendidik dan membimbing) peserta didik sebagaimana mendidik anaknya sendiri.

\section{Kualitas Profesional}

Kualitas profesional merupakan nilai yang mencerminkan sejauhmana seseorang mampu dan menguasai pekerjaan dalam hal ini adalah mampu menguasai pelajaran. Temuan lapangan menunjukkan kualitas profesional guru madrasah pesantren perempuan lebih tinggi dibandingkan kualitas profesional guru madrasah pesantren laki-laki. Kualitas profesional pada guru madrasah pesantren laki-laki sebesar $3,64 \%$ dan kualitas profesional pada guru madrasah perempuan sebesar $10,80 \%$.

Kualitas profesional dibentuk oleh beberapa hal, seperti profesional, berwawasan luas, terampil, menguasai tugas pokok guru, independent, dan terampil. Istilah kualitas profesional lebih dikenal dengan kompetensi profesional dalam dunia pendidikan. Kompetensi profesional diartikan sebagai salah satu kompetensi yang wajib dimiliki guru dimana guru menguasai pelajaran secara menyeluruh (Nanat Fatah Natsir, 2007: 2223).

\section{Nilai Religiusitas}

Nilai religiusitas dalam penelitian terdiri dari beberapa karakter seperti ibadah, niat, keikhlasan, moral, ladang mencari kebahagiaan dunia akhirat, tauhid, toleransi, berpegang teguh pada Al-Qur'an dan AlHadist. Maksud kata religiusitas dalam penelitian ini adalah religiusitas dalam konteks psikologi, seperti yang dikemukakan oleh Allport dan Ross (1976) (Fridayanti, 2016: 200) dengan konsep religiusitas instrinsik dan ekstrinsik yang menggambarkan aspek motivasional dalam beragama. Diperkuat oleh Glock dan Stark (1968) (Fridayanti, 2016: 200) tentang komitmen religius untuk menjelaskan komitmen terhadap substansi agama, yaitu aspek pengetahuan, keyakinan, praktik, perasaan dan konsekuensi. Hasil penelitian menunjukkan bahwa nilai religiusitas pada guru madrasah pesantren laki-laki lebih besar, yaitu $22,43 \%$ dibandingkan nilai religiusitas pada guru madrasah pesantren perempuan sebesar 10,21\%. Hasil ini berbeda dengan penelitian Afiatin (1998:59) yang menunjukkan tidak ada perbedaan religiusitas dan dimensi-dimensi antara pria dan wanita. Agata dan Sidabutar (2015) juga menyatakan hal yang serupa bahwa tidak ada perbedaan yang signifikan pada religiusitas laki-laki dan perempuan (Agata \& Sidabutar, 2015: 354). Perbedaan hasil penelitian ini dengan dua penelitian yang telah disebutkan diatas menjadi suatu fenomena yang perlu ditindaklanjuti terkait religiusitas antara lakilaki dan perempuan.

\section{Nilai Material}

Nilai material merujuk pada konsep segala hal yang berguna bagi jasmani. Nilai material hanya muncul bagi guru madrasah pesantren laki-laki. Nilai material bukanlah nilai yang dominan muncul, hanya 1,22\%. Nilai material yang muncul dalam penelitian ini adalah gaji. Gaji merupakan salah satu alat ukur unt uk mengukur nilai kerja pada Chinese General Social Survey (CGSS) untuk mengukur nilai kerja pada karyawan (Nie et al., 2014: 56). Hasil ini didukung oleh survey Hawthorne dari 1927-1932 yang memperlihatkan bahwa laki-laki lebih memperdulikan mengenai upah dan kondisi kerja daripada perempuan, sebagai pembanding, wanita lebih peduli relasi sosial daripada laki-laki (Roethlisberger dan Dickson, 1939/1975) (Nie et al., 2014: 54).

\section{Nilai Status}

Stat us dalam penelitian ini terdiri dari beberapa kategori seperti penghargaan dan status. Status merupakan salah satu dari nilai kerja ektrinsik (Vansteenkiste et al., 2007: 258). Status terbentuk dari kebutuhan pengakuan, wewenang dan status sosial. Status dapat diartikan sebagai pentingnya lingkungan untuk memberikan pengakuan dan penghargaan (Putranto \& Ingarianti, 2014: 117). Berdasarkan hasil temuan lapangan diketahui bahwa nilai kerja status pada guru madrasah pesantren laki-laki lebih tinggi 
dibandingkan dengan nilai kerja pada guru madrasah pesantren perempaun. Nilai kerja stat us pada guru madrasah pesantren laki-laki $2,42 \%$ dan nilai kerja status pada guru madrasah pesantren perempuan sebesar $1,14 \%$.

\section{Nilai Ukhuwah Islamiyah}

Nilai ukhuwah Islamiyah merupakan istilah yang identik dengan Islam. Ukhuwah Islamiyah merupakan pancaran dari pesona kedamaian, ketenangan dan keharmonisan perilaku (Suyudi dan Rahmatullah, 2017:238). Nilai ukhuwah Islamiyah dalam penelitian ini terdiri dari beberapa kategori seperti hubungan persaudaraan dengan sesama (relationship), senang menolong, mengasuh, mengontrol, membimbing santri diluar KBM, dan memotivasi santri. Hasil temuan lapangan menunjukkan bahwa nilai ukhuwah Islamiyah pada guru madrasah pesantren laki-laki lebih tinggi $(8,48 \%)$ dibandingkan nilai ukhuwah Islamiyah pada guru madrasah pesantren perempuan $(3,41 \%)$.

\section{Nilai Komitmen Organisasi}

Nilai komitmen organisasi muncul karena adanya beberapa kategori seperti loyalitas, komitmen (istiqomah), pengorbanan, dedikasi, dan integritas. Komitmen organisasi yang dimaksud dalam penelitian ini adalah komitmen organisasi sebagai sikap, seperti yang dikemukakan oleh Luthans (Luthans, 2006: 249). Sikap yang pertama adalah keinginan kuat untuk berusaha keras sesuai keinginan organisasi, sikap kedua adalah keinginan kuat untuk tetap sebagai anggota organisasi, dan sikap ketiga adalah keyakinan tertentu dan penerimaan nilai dan tujuan organisasi. Hasil penelitian menunjukkan bahwa nilai komitmen organisasi pada guru madrasah laki-laki lebih tinggi (7,27\%) dibandingkan dengan nilai komitmen organisasi pada guru madrasah pesantren perempuan $(4,35 \%)$.

\section{Nilai Sosial}

Nilai sosial hanya muncul pada guru madrasah pesantren perempuan sebesar 1,14\% dari kategori dukungan dan kondisi kerja.
Dukungan yang dimaksud adalah dukungan dari rekan maupun atasan sedangkan kondisi kerja diartikan sebagai kondisi sosial pekerjaan, seperti interaksi antara guru dengan siswa, rekan sejawat maupun atasan. Hasil ini didukung oleh survey Hawthorne dari 1927-1932 yang memperlihatkan bahwa laki-laki lebih memperdulikan mengenai upah dan kondisi kerja daripada perempuan, sebagai pembanding, wanita lebih peduli tentang relasi sosial daripada laki-laki (Roethlisberger dan Dickson, 1939/1975) (Nie et al., 2014: 54).

Nilai kerja yang mengarah kepada relasi sosial atau hubungan dengan orang lain disebut Hofstade sebagai feminin. Masyarakat feminin digambarkan sebagai masyarakat yang mengutamakan hubungan dengan sesama, memperhatikan orang lain (JM Ivancevich, R Konpaske, 2007: 42-43).

\section{Nilai Achievement}

Nilai achievement atau prestasi hanya ada pada guru madrasah pesantren perempuan sebesar $1,14 \%$. Prestasi diartikan sebagai pentingnya lingkungan yang mendorong individu untuk berprestasi. Nilai prestasi menjadi salah satu dimensi nilai kerja apabila ditinjau dari struktur kepribadian yang muncul karena adanya berbagai kebutuhan seperti penggunaan kemampuan, prestasi, kegiatan, dan kebebasan (Putranto \& Ingarianti, 2014: 117).

Hasil temuan lapangan menunjukkan bahwa nilai kerja yang dimiliki guru madrasah pesantren laki-laki secara berurutan dari nilai kerja dengan persentase tertinggi hingga nilai kerja dengan persentase terendah adalah (1) kualitas kepribadian, (2) nilai religiusitas, (3) kualitas akademik, (4) nilai ukhuwah Islamiyah, (5) nilai komitmen organisasi, (6) kualitas profesional, dan (7) stat us serta yang terendah adalah nilai material. Adapun nilai kerja guru madrasah pesantren perempuan dari nilai kerja dengan persentase tertinggi hingga nilai kerja dengan persentase terendah adalah (1) kualitas kepribadian, (2) kualitas akademik, (3) kualitas profesional, (4) nilai religiusitas, (5) nilai komitmen organisasi, (6) nilai ukhuwah Islamiyah, (7) achievement, (8) stat us, dan terakhir (9) nilai sosial. 
Perbedaan nilai yang dimiliki oleh guru madrasah pesantren laki-laki dan perempuan adalah jika pada guru madrasah pesantren laki-laki tidak muncul nilai sosial dan achievement seperti yang muncul pada guru madrasah pesantren perempuan. Hasil ini didukung oleh pernyataan Anoraga bahwa perempuan dapat bekerja seperti laki-laki, bahkan terkadang kinerja maupun prestasi perempuan lebih baik dari pada laki-laki (Anoraga, B., \& Prasetyo, 2015: 121). Terkait nilai sosial yang hanya muncul pada guru madrasah pesantren perempuan atau dengan kata lain perempuan lebih mementingkan relasi sosial atau nilai sosial dibandingkan laki-laki, maka hasil penelitian ini sesuai dengan pendapat Hawthorne (Nie et al., 2014: 54) dan Hofstade (Dayakisni, T., \& Yuniardi, 2012: 211) bahwa perempuan lebih mementingkan hubungan interpersonal atau hubungan sosial.

Sedangkan pada guru madrasah perempuan tidak adanya nilai material, seperti yang ada pada guru madrasah laki-laki. Hal ini merupakan suatu kewajaran, karena di Jawa khususnya Ponorogo laki-laki merupakan kepala rumah tangga yang memiliki kewajiban dan tanggungjawab mencari nafkah untuk keluarga. Keadaan tersebut sesuai dengan pendapat Hofstade tentang masyarakat maskulin yang lebih mengutamakan pendapatan, pengakuan, kemajuan, dan tantangan dibandingkan relasi sosial (Dayakisni, T., \& Yuniardi, 2012: 211).

\section{Faktor yang Membentuk Nilai Kerja Guru}

Temuan di lapangan mendapatkan lima puluh lima (55) kategori pada subjek lakilaki dan empat puluh tiga (43) pada subjek perempuan. Setelah itu subjek diminta memberi jawaban minimal tiga jawaban, diperoleh rincian sebagai berikut.

Lima puluh lima kategori diperoleh dari proses koding pertama, selanjutnya melakukan koding tahap kedua dengan teknik reduksi data dan mendapatkan delapan (8) faktor yang membentuk nilai kerja guru madrasah pesantren laki-laki, seperti: (1) lingkungan kerja; (2) kepribadian; (3) pemimpin; (4) status sosial ekonomi; (5) culture/kebudayaan; (6) religiusitas; (7) kepuasan kerja; dan (8) nilai sosial. Berikut merupakan rincian kedelapan kategori tersebut:

Faktor pembentuk nilai kerja pada guru madrasah pesantren perempuan yang terdiri dari faktor lingkungan kerja, kepribadian, status sosial ekonomi, kebudayaan, pemimpin, religiusitas, reward, dan kepuasan kerja.

Empat puluh tiga (43) kategori diperoleh dari proses koding pertama, selanjutnya melakukan koding tahap kedua dengan teknik reduksi data dan mendapatkan sembilan (9) faktor yang membentuk nilai kerja guru madrasah pesantren perempuan, seperti : (1) lingkungan kerja; (2) kepribadian; (3) pemimpin; (4) status sosial ekonomi; (5) culture/ kebudayaan; (6) religiusitas; (7) kepuasan kerja (8) reward; dan (9) lain-lain.

\section{Lingkungan Kerja}

Faktor utama yang membentuk nilai kerja guru madrasah pesantren laki-laki dan perempuan adalah lingkungan kerja. Faktor lingkungan kerja pada penelitian ini terbentuk atas beberapa kategori seperti fasilitas, komunikasi dengan rekan maupun atasan, keadaan siswa, dukungan teman, tempat, peraturan sekolah, manajemen madrasah, tim kerja, sekolah dan teman, serta kebijakan kepala sekolah. Temuan penelitian bahwa lingkungan menjadi salah faktor yang membentuk nilai kerja sesuai dengan pendapat Hofstade (1980:81-94) (Fikri, 2015: 44-45), hal itu karena baik lingkungan kerja fisik maupun lingkungan kerja sosial yang dialami individu selama berada ditempat kerja akan memunculkan dorongan untuk menilai pada suatu hal dan mempengaruhi pada nilai kerja individu yang bersangkutan. Hasil penelitian menunjukkan jika faktor lingkungan kerja lebih mempengaruhi nilai kerja pada guru madrasah perempuan, sebesar 36,11\% dibandingkan pada guru madrasah pesantren laki-laki, yaitu 27,63\%.

\section{Kepribadian}

Kepribadian atau personality merupakan ciri-ciri watak seseorang individu yang konsisten sehingga memberi identitas khusus pada individu (Koentjoroningrat, 2002: 102). 
Kepribadian juga menjadi salah faktor pembentuk nilai kerja pada guru madrasah pesantren laki-laki dan perempuan. Faktor kepribadian lebih membentuk nilai kerja pada guru madrasah pesantren laki-laki $(34,16 \%)$ dibandingkan guru madrasah perempuan $(27,09 \%)$. Kepribadian sendiri terbentuk dari beberapa kategori, yaitu disiplin, tanggung jawab, karakter individu, konsep diri, jujur, memenuhi kebutuhan jasmani rohani, kinerja diri, niat, karir, kondisi fisik, ingin membentuk generasi yang berkualitas islami, pengalaman kerja dan optimis. Hasil penelitian ini tidak ditemukan secara spesifik bahwa nilai kerja juga dapat dipengaruhi kepribadian seseorang, tetapi Hofstade (1980:81-94) (Fikri, 2015: 44-45) menyebut salah satu faktor yang mempengaruhi nilai kerja adalah tujuan personal.

Tujuan personal merupakan bagian dari unsur kepribadian manusia. Tujuan personal diartikan sebagai target yang ingin dicapai oleh karyawan dan membuat karyawan mengerahkan semua kemampuan untuk mencapai tujuan. Tujuan personal akan dapat tercapai ketika individu memiliki kepribadian yang berkualitas. Kepribadian yang berkualitas, yaitu seperti disiplin, tanggung jawab, jujur, optimis, memiliki pengalaman, dan lain-lain.

\section{Pemimpin}

Pemimpin dan ustadz/guru juga menjadi salah faktor yang membentuk nilai kerja guru madrasah pesantren laki-laki, sebesar $10,06 \%$ dan guru madrasah pesantren perempuan sebesar $7,64 \%$. Pemimpin yang dimaksud adalah kyai, pemimpin madrasah maupun ustadz ustadzah di pondok pesantren. Sosok pemimpin, yaitu kyai maupun ustadz merupakan sosok yang disegani dalam pesantren sehingga menjadi teladan bagi para guru madrasah dan dapat membentuk nilai kerjanya. Khususnya kyai yang merupakan sosok esensial dari pesantren, karena seringkali sebagai pendiri pesantren. Sehingga idealnya pertumbuhan dan perkembangan pesantren bergantung kepada kemampuan pribadi kyainya, termasuk kemampuan mentransfer nilai-nilai dasar pesantren kepada guru maupun santri (Ni'mah, 2016: 248).

\section{Status Sosial Ekonomi}

Status sosial ekonomi menjadi salah satu faktor yang membentuk nilai kerja guru madrasah pesantren. Faktor status sosial ekonomi terdiri dari pendapatan, tingkat pendidikan, masyarakat, dan pergaulan. Hasil ini didukung oleh Chen (1995) (Jayanti et al., 2016: 80) yang menyatakan bahwa pembentukan nilai kerja dapat dipengaruhi oleh faktor sejarah sosiologis, ekonomis, dan faktor historis, termasuk etnis, subkultur, peran seks, sejarah pengikut, status sosial ekonomi, dan kondisi ekonomi. Pengaruh faktor status sosial ekonomi lebih mempengaruhi nilai kerja guru madrasah perempuan, yaitu sebesar $9,27 \%$ dibandingkan pada guru madrasah pesantren laki-laki sebesar 3,15\%.

\section{Culture/ Kebudayaan}

Culture/ kebudayaan merupakan salah satu faktor yang membentuk nilai kerja. Kebudayaan diartikan sebagai "hal-hal yang bersangkutan dengan budi atau akal" (Soekanto, 2006: 150). Kategori yang termasuk kebudayaan berdasarkan hasil temuan lapangan adalah budaya, perkembangan zaman, keluarga, dan pola asuh.

Pola asuh merupakan bagian dari bentuk komunikasi dalam keluarga untuk mentransfer kebiasaan atau nilai-nilai dalam keluarga. Keluarga menjadi bagian dari unsur kebudayaan. Sesuai dengan pendapat Melville J. Herskovits yang mengajukan empat unsur kebudayaan, seperti alat-alat teknologi, sistem ekonomi, keluarga, dan kekuasaan politik (Soekanto, 2006: 153). Jadi, budaya merupakan salah satu faktor yang membentuk nilai kerja guru madrasah pesantren, karena terdapat unsur normatif yang merupakan bagian dari kebudayaan. Salah satu unsur normatif kebudayaan adalah unsur yang menyangkut penilaian (valuational elements) misalnya apa yang dianggap benar dan salah, apa yang sesuai keinginan dan tidak sesuai keinginan (Soekanto, 2006: 158). Hasil ini didukung oleh penelitian Chen (1995) (Jayanti et al., 2016: 80) yang menyatakan salah satu faktor pembentukan nilai kerja adalah 
subkultur. Subkultur merupakan hasil perkembangan kultur yang tidak bertentangan dengan kebudayaan induk (Soekanto, 2006: 158). Faktor kebudayaan memiliki pengaruh yang hampir sama baik kepada guru madrasah pesantren laki-laki $(8,18 \%)$ dan pada guru madrasah pesantren perempuan $(8,33 \%)$, karena memiliki nilai persentase yang hampir sama.

\section{Religiusitas}

Menurut Allport dan Ross (1976) (Fridayanti, 2016: 200) yang mempelopori konsep orientasi religiusitas (religiusitas intrinsik dan ektrinsik) yang menggambarkan aspek motivasional dalam beragama. Faktor religiusitas terbentuk dari beberapa kategori, yaitu keikhlasan, ibadah, pengabdian kepada Allah dan manusia, berakhlak mulia/ uswatun hasanah, faktor religiusitas, menjalankan perintah dalam Al-Qur'an dan Hadis dan memberi kontribusi dengan mengharap pahala dan surga. Persentasi religiusitas pada guru madrasah pesantren laki-laki adalah 13,84\% sedangkan pada guru madrasah pesantren perempuan sebesar $5,55 \%$, artinya faktor religiusitas lebih mempengaruhi guru madrasah pesantren laki-laki dalam membentuk nilai kerja dibandingkan dengan guru madrasah pesantren perempuan.

\section{Kepuasan Kerja}

Kepuasan kerja juga menjadi salah satu faktor yang membentuk nilai kerja guru madrasah pesantren baik laki-laki maupun perempuan. Hasil ini juga didukung oleh pendapat Hofstade (1980:81-94) (Fikri, 2015: 44-45) menyatakan bahwa kepuasan karyawan dalam pekerjaannya menentukan nilai kerja. Kepuasan kerja diartikan sebagai keseluruhan dalam pekerjaan. Semakin puas karyawan terhadap pekerjaan maka akan semakin mempengaruhi nilai kerja (nilai kerjanya meningkat). Hasil temuan lapangan menunjukkan jika faktor kepuasan kerja memiliki pengaruh yang hampir sama, baik kepada guru madrasah pesantren laki-laki $(0,63 \%)$ maupun kepada guru madrasah pesantren perempuan $(0,69 \%)$ karena memiliki nilai persentase yang hampir sama.

\section{Reward}

Reward hanya menjadi salah faktor yang membentuk nilai kerja bagi guru madrasah pesantren perempuan, yaitu sebesar $2,78 \%$. beberapa kategori yang termasuk dalam reward adalah tunjangan, apresiasi dan kesejahteraan guru.

Berdasarkan pembahasan hasil temuan lapangan mengenai faktor-faktor yang membentuk nilai kerja pada guru madrasah pesantren laki-laki dan perempuan adalah (1) faktor lingkungan kerja; (2) faktor kepribadian; (3) faktor pemimpin; (4) faktor status sosial ekonomi; (5) faktor culture/ kebudayaan; (6) faktor religiusitas; (7) faktor kepuasan kerja; dan pada guru madrasah perempuan ada faktor reward.

Apabila diurutkan dari angka persentase yang paling besar hingga yang paling kecil, maka faktor yang membentuk nilai kerja guru madrasah pesantren laki-laki adalah (1) kepribadian; (2) lingkungan kerja; (3) religiusitas; (4) pemimpin; (5) kebudayaan; (6) status sosial ekonomi; dan yang terakhir faktor kepuasan kerja. Adapun urutan faktor yang membentuk nilai kerja guru madrasah pesantren perempuan dari angka persentase yang paling besar sampai yang terendah adalah : (1) lingkungan kerja; (2) kepribadian; (3) status sosial ekonomi; (4) kebudayaan; (5) pemimpin; (6) religiusitas; (7) reward; dan yang terakhir kepuasan kerja.

Perbedaan urutan faktor pembentuk nilai kerja pada guru madrasah pesantren dapat dianalisis menggunakan teori Hofstade, khususnya pada dimensi kemaskulian. Menurut teori Hofstade masyarakat yang feminin menekankan pada hubungan dengan sesama, memperhatikan orang lain, dan kualitas hidup secara keseluruhan. Sementara masyarakat maskulin, menekankan pada ketegasan dan penguasaan akan uang serta hal-hal yang bersifat materi, namun tidak berempati kepada orang lain (Ivencevich, J. M., Konopaske, R., \& Matteson, 2007: 42-43).

Teori ini sesuai dengan hasil temuan faktor pembentuk nilai kerja pada guru madrasah pesantren perempuan yang memperlihatkan urutan dari faktor lingkungan yang berkaitan erat dengan keadaan disekitar baik dalam bentuk fisik maupun sosial. Selanjutnya faktor kepribadian dan status sosial ekonomi, keduanya masih berkaitan 
erat dengan cara individu unt uk berhubungan dan menjalin komunikasi dengan lingkungan sosial.

Adapun tiga faktor utama yang membentuk nilai kerja guru madrasah pesantren laki-laki adalah kepribadian, lingkungan kerja, dan religiusitas. Ketiga faktor ini kurang sesuai denga teori Hofstade terkait kemaskulinan dan feminin. Hal ini membuktikan jika nilai kerja guru madrasah pesantren laki-laki lebih dipengaruhi oleh faktor intrinsik, yaitu kepribadian individu dan religiusitas. Kedua faktor diatas tidak dapat dikategorikan dalam masyarakat maskulin maupun feminin. Sehingga berdasarkan pembahasan diatas, dapat ditarik kesimpulan bahwa perbedaan gender masih menentukan faktor pembentuk nilai kerja yang mengakibatkan adanya perbedaan orientasi kerja antara laki-laki dan perempuan. Hasil ini didukung oleh pernyataan Chen (1995) (Jayanti et al., 2016: 80) bahwa peran seks dapat mempengaruhi nilai kerja pada diri seseorang.

\section{PENUTUP}

Temuan penelitian menunjukkan bahwa nilai kerja guru laki-laki pada madrasah berbasisis pesantren terdiri atas: (1) kualitas kepribadian, (2) nilai religiusitas, (3) kualitas akademik, (4) nilai ukhuwah Islamiyah, (5) nilai komitmen organisasi, (6) kualitas profesional, (7) stat us, dan (8) nilai material. Sedangkan nilai kerja guru perempuan pada madrasah berbasis pesantren terdiri atas: (1) kualitas kepribadian, (2) kualitas akademik, (3) kualitas profesional, (4) nilai religiusitas, (5) nilai komitmen organisasi, (6) nilai ukhuwah Islamiyah, (7) achievment, (8) stat us, dan (9) nilai sosial.

Faktor pembentuk nilai kerja guru laki-laki pada madrasah berbasis pesantren laki-laki meliputi: (1) faktor kepribadian, (2) lingkungan kerja, (3) religiusitas, (4) pemimpin, (5) kebudayaan, (6) status sosial ekonomi, dan (7) kepuasan kerja. Sementara faktor pembentuk nilai kerja guru perempuan pada madrasah berbasis pesantren meliputi: (1) faktor lingkungan kerja, (2) kepribadian, (3) status sosial ekonomi, (4) kebudayaan, (5) pemimpin, (6) religiusitas, (7) reward, dan (8) kepuasan kerja.

Berdasarkan hasil penelitian dapat disampaikan beberapa saran diantaranya: (1) Hasil penelitian ini memberikan informasi kepada pengelola pesantren (kyai, ustadz, stakeholder) terkait gambaran nilai kerja guru madrasah berbasis pesantren. Harapannya para pemimpin madrasah berbasis pesantren dapat melakukan evaluasi nilai kerja yang dimiliki guru. Dengan demikian, pengelola pesantren dapat merencanakan strategi agar nilai kerja guru madrasah berbasis pesantren sesuai dengan visi misi pesantren (nilai-nilai Islam). (2) Hasil penelitian ini dapat dikembangkan melalui tindaklanjut dengan metode lain, misalnya menggunakan metode indigenous psikologi atau menggunakan pertanyaan terbuka (open-ended questionare).

\section{DAFTAR PUSTAKA}

Abdullah, N. A., Omar, F., Nik Mutasim, N. M. N., \& Adham, K. A. 2013. Conceptualizing work and organizational values from the Islamic perspective. Jurnal Pengurusan. https://doi.org/10.17576/pengurusan2013-39-11

Agata, W., \& Sidabutar, F. M. 2015. Pengaruh Religiusitas Terhadap Gratitude Pada Remaja Yang Tinggal Di Panti Asuhan Kristen. Jurnal Psikologi Ulayat. https://doi.org/10.24854/jpu12015-31

Anoraga, B., \& Prasetyo, A. 2015. Motivasi Kerja Islam Dan Etos Kerja Islam Karyawan Bank Jatim Syariah Cabang Surabaya. JESTT.

As'ad, M. 2004. Seri Ilmu Sumber Daya Manusia Psikologi Industri.

Yogyakarta: Liberty.

Bisman, C. 2004. Social Work Values: The Moral Core of the Profession. British Journal of Social Work. https://doi.org/10.1093/bjsw/bch008

Dayakisni, T., \& Yuniardi, S. 2012. Psikologi Lintas Budayae. Malang: UMM Press.

Dzulkifli, \& Sari, I. P. 2015. Karakteristik Guru Ideal. Seminar Psikologi Dan Kemanusian. 
Fikri, R. 2015. Hubungan Antara Relational Mobility Dengan Work Value Pada Individu Dewasa Yang Memiliki Mobilitas Sosial Rendah. UNNES.

Fridayanti, F. 2016. Religiusitas, Spirit ualitas Dalam Kajian Psikologi Dan Urgensi Perumusan Religiusitas Islam. Psympathic: Jurnal Ilmiah Psikologi. https://doi.org/10.15575/psy.v2i2.460

Irham, M. 2012. Etos Kerja dalam Perspektif Islam. Jurnal Substantia, 11-24.

Ivencevich, J. M., Konopaske, R., \& Matteson, M. T. (2007). Perilaku Dan Manajemen Organisasi Jilid 1. Jakarta: Erlangga.

Jayanti, F. A., Suharsono, Y., \& Ingarianti, T. M. (2016). Nilai Kerja Pada Anggota Tni-Ad Berdasarkan Tahapan Karir. Psympathic: Jurnal Ilmiah Psikologi. https://doi.org/10.15575/psy.v2i1.449

JM Ivancevich, R Konpaske, M. M. 2007. Perilaku dan Manajemen Organisasi Jilid 1. Jakarta: Erlanggga.

Judge, T. A., \& Bretz, R. D. 1992. Effects of Work Values on Job Choice Decisions. Journal of Applied Psychology. https://doi.org/10.1037/00219010.77.3.261

Knoop, R. 1994. Work values and job satisfaction. Journal of Psychology: Interdisciplinary and Applied. https://doi.org/10.1080/00223980.1994 .9921297

Koentjoroningrat. 2002. Pengantar Ilmu Antropologi. Jakarta: PT Rineka Cipta.

Luthans, F. 2006. Perilaku Organisasi. Yogyakarta: Andi Offset.

Meglino, B. M., Ravlin, E. C., \& Adkins, C. L. 1992. The Measurement of Work Value Congruence: A Field Study Comparison. Journal of Management. https://doi.org/10.1177/014920639201 800103

Morrisan. 2012. Metode Penelitian Survei. Jakarta: Kencana.

Nanat Fatah Natsir. 2007. Peningkatan Kualitas Guru dalam Perspektif Pendidikan Islam. Educationist.

Ni'mah, U. 2016. Manajemen Madrasah Berbasis Nilai Pesantren Di Mts AlIslam Joresan. Muslim Heritage.

Nie, L., Ye Luo, M., Wentworth, W. M., \& Sturkie, D. K. 2014. Gender, Family,
Socioeconomic Status, and Work Values in China. American International Journal of Social Science.

Primasari, A., \& Yuniarti, K. W. 2012. What make teenagers happy? An exploratory study using indigenous psychology approach. International Journal of Research Studies in Psychology. https://doi.org/10.5861/ijrsp.2012.v1i2. 80

Putranto, N. H. N. H., \& Ingarianti, T. M. 2014. Nilai Kerja Pada Wanita Yang Bekerja. Jurnal Psikologi Teori Dan Terapan.

https://doi.org/10.26740/jptt.v4n2.p11 3-129

Putri, A. K., Prawitasari, J. E., Hakim, M., Yuniarti, K. W., \& Kim, U. 2012. Sadness As Perceived By Indonesia Male Dan Female Adolescents. International Journal of Research Studies In Psychology.

Rarasati, N., Hakim, M., \& Yuniarti, K. W. 2012. Javanese Adolescents'future Orientation And Supports For Its Effort: An Indigenous Psychological Analysis. International Journal Of Psychological And Behavioral Sciences.

Ravlin, E. C., \& Meglino, B. M. 1987. Effect of Values on Perception and Decision Making: A Study of Alternative Work Values Measures. Journal of Applied Psychology.

https://doi.org/10.1037/00219010.72.4.666

Robbins, S. 2002. Prinsip-Prinsip Perilaku Organisasi (Edisi Keli). Jakarta: Erlangga.

Soekanto, S. 2006. Sosiologi Suatu Pengantar. Jakarta: PT Raja Grafindo.

Styaningsih, R. 2016. Kontinuitas Pesantren dan Madrasah di Indonesia. AT TA'DIB. https://doi.org/10.21111/attadib.v11i1.651

Sugiyono. 2012. Metode Penelitian Kuantitatif, Kualitatif dan $\mathrm{R}$ \& D.Bandung:Alfabeta. Metode Penelitian Kuantitatif, Kualitatif Dan R \& D.Bandung:Alfabeta. https://doi.org/10.1017/CBO97811074 15324.004 
Suwardi. 2005. Nilai Kerja dalam Budaya Organisasi Sekolah Tinggi Agama Islam Negeri Salatiga. Jurnal Penelitian Dan Evaluasi Pendidikan, 273-288.

TA Judge, M. 1992. The Effect Of Work Values On Absence Disciplinary Decisions: The Role Of Fairness Orientation And Supervisor Attributions. CAHRS Working Paper.
Utama. 2013. Gambaran Perbedaan NilaiNilai Kerja antara Dokter dan Perawat di Rumah Sakit. Jurnal Psikologi.

Vansteenkiste, M., Neyrinck, B., Niemiec, C. P., Soenens, B., De Witte, H., \& Van Den Broeck, A. 2007. On the relations among work value orientations, psychological need satisfaction and job outcomes: A self-determination theory approach. Journal of Occupational and Organizational

Psychology. https://doi.org/10.1348/096317906X11 1024 